\title{
Tracking Jordan Destination Image Using the Same Sample
}

\author{
Areej Shabib Aloudat ${ }^{1} \&$ Akram Rawashdeh ${ }^{1}$ \\ ${ }^{1}$ Department of Tourism and Travel, Yarmouk University, Irbid, Jordan \\ Correspondence: Areej Shabib Aloudat, Yarmouk University, 21163 P.O. Box (566), Irbid, Jordan. E-mail: \\ arige12@hotmail.com
}

Received: June 27, 2012 Accepted: December 25, 2012 Online Published: February 28, 2013

doi:10.5539/ijms.v5n2p59 URL: http://dx.doi.org/10.5539/ijms.v5n2p59

\begin{abstract}
The aim of this paper is to track Jordan destination image using the same sample. The perceptions of tourists visiting Jordan on the pre- and post- visit images of Jordan were analysed. A total of 179 questionnaires were distributed by the assistance of tour guides who joined the tourists in their trip in Jordan. The distribution was accomplished into two stages for the same sample, in the first day of coming to Jordan, and in the last day of the trip during their way back to the airport. The results indicated that: (1) Petra, natural beauty, and the Dead Sea were among the first motivations for the tourists to visit Jordan; and (2) except for the price levels, the post- image was more positive than the pre-image of Jordan. Thus, the results reflect that Jordan is not promoted properly according to its actual performance. The study is an addition to the limited literature that tracked destination image using the same sample. It provided more understanding of the image of Jordan as a tourism destination.
\end{abstract}

Keywords: destination image, pre- and post images, Jordan image, same sample

\section{Introduction}

Since the First World War Jordan has given attention to tourism as one of the models of economic development. Earlier tourism trips were taken by independent travellers to the holy land in Jerusalem and Bethlehem, in addition to some journeys to Petra (El-Roudan, Al-Ardah \& Tal'at, 2000:7). Despite the inadequate tourism infrastructure, promotional campaigns started to take place and tourists began to arrive to Jordan. The government then turned to develop tourism infrastructure and to train human resources. Thereafter, in 1963, the Royal Jordanian Airlines was founded in order to meet tourism demand (Gray, 2002: 310). Historically, tourism has grown about seven percent a year (Reid \& Schwab, 2006) generating around 12.4 percent of the Kingdom's gross domestic product (Jordan National Tourism Strategy, 2011).

Today, tourism is an important sector in Jordan. It has played a key role in the development of the Jordanian economy. In 2011, the number of overnight tourists was 3.959 .651 tourists. This number represents 7 percent of the Middle East share and 0.4 percent from the international tourism volume (Ministry of Tourism and Antiquities (MOTA). In terms of employment, tourism is considered as the second largest private sector employer in Jordan approximately 41.749 direct jobs. The majority of these jobs are generated by tourism restaurants and the hotel industry, with a share of 40.3 percent and 36.1 percent respectively ( (MOTA), 2011). Tourism is also the kingdom's second largest export sector, contributing more than two billion US\$ to Jordan's economy and it is, after receipts from remittances, the second highest producer of foreign exchange, contributing an average of 20 percent of foreign exchange sources (El-Roudan et al. 2000; MOTA, 2011) despite that tourism to Jordan was and still affected by a series of regional and global events, more recently affected by the new Arab revolutions or what it has become known as the "Arab Spring".

Little marketing studies have been conducted (Schneider \& Sönmez, 1999) about the image of Jordan as a tourism destination (Schneider \& Sönmez, 1999; Alshourah, 2001; Harahsheh, 2009). Accordingly, this study offers an empirical analysis of Jordan's perception among the international tourists by comparing travellers' pre -and -post perceptions, the findings can be used by tourism bodies and tourism researchers to further understandings the image of Jordan.

Additionally, it has been found that tourism experience is fluctuated according to passage of time ( $\mathrm{Li}$, Cheng, Kim $\&$ Petrick, 2008). However, in tourism literature, few studies have used the same sample to compare between the pre- and post- visit images (Kim, McKercher, \& Lee, 2009). Gallarza, Saura, \& Garcia, 2002) suggested that 'the correct way of assessing the influence of time on image formation should be not the comparisons of different 
samples but longitudinal sampling studies, although this kind of research is difficult in tourism' (Gallarza, et la., 2002:61). Therefore, in a try to get more accurate answers, this study tracked the image of Jordan using the same sample.

\section{Literature Review}

The importance of tourism destination image make it one of the most researched topics in the tourism literature (Pike, 2002; Kim, Mckercher, \& Lee, 2009; Lin \& Huang, 2009; Mazanec \& Wober, 2010). Researchers have conceptualized the notion of image differently (Pearce 1988; Fakeye \&Crompton, 1991; Jenkins, 1999; Mazanec \& Wober, 2010). However, the term is still indistinct and holds different meanings (Choi, Lehto\& Morrison, 2007). 'Image is one of those terms that will not go away.... a term with vague and shifting meanings' (Pearce, 1988:162).

Nevertheless, image has been defined by different scholars (Crompton, 1979; Gertner \& Kotler, 2004; Lin \& Huang, 2009; Reid\& Bojanic, 2009). Lin and Huang (2009) defined image as 'sensual, aesthetic and emotional dimensions, of a space'. Reid and Bojanic (2009) defined it as 'the impression a person holds about a destination in which he does not reside' (Reid\& Bojanic, 2009:610). A definition of Chon (1990) -which the researchers preferis the interaction of person's beliefs, feelings and impressions about an object. This definition highlights the subjective feelings and personal dimensions that conceptualize the notion of image.

Tourism literature has demonstrated that destination image is a crucial factor in the selection of tourism destinations and therefore in the flows of tourists (Hunt, 1975; Goodrich, 1978; May \& Jarris, 1981, Fakeye \& Crompton, 1991; Chon, 1991; Echtner \& Ritchie, 1991; Pike, 2002).

Two kinds of destination images have been distinguished in the literature (Gunn 1972; Gartner, 1993). Gunn (1972) is the first to view image as both organic and induced. According to Gunn (1972) the organic (mental) image is the image that is accumulated from the non-commercial sources such as news, and the word of mouth (WOM) gained from friends and relatives while the induced (initial) image is shaped from the information attained from commercial sources such as advertising and tour operators and travel agencies. However, the literature demonstrated that the formation of destination image is influenced not only by the source of information in the destination itself but also by other factors including: tourism motivation; socio-economic; and demographic characteristics of the tourists (Mayo\& Jarvis, 1981; Beerli \& Martin, 2004; Kim, McKercher, \& Lee, 2009).

Other studies have researched the pre- and the post- visits perceived images of the destination (Pearce,1982; Gunn, 1988; Fakeye \& Crompton, 1991; Garter, 1993; Baloglu \& Macheraly, 1999; Grosspietsh, 2004; Kim, McKercher, \& Lee, 2009; Wang \& Davidson, 2010).The pre-visit image may involve both the organic and the induced images while the post-visit image may refer to the experiential image that is accumulated from the first moments of arriving at the host destination until returning back to the home country.

As mentioned before, little research has been done on Jordan tourism image. To date, only three studies have been found that investigated the image of Jordan as perceived by international tourists (Schneider \& Sönmez, 1999; Alshourah, 2001; Harahsheh, 2009). Schneider and Sönmez (1999) have studied the image of Jordan as perceived by Jerash's festival visitors. The findings revealed that the visitors had a positive image about Jordan with a high rating to the dimensions of safety, hospitality, and the diversity in tourism sites. However, the sample was more neutral in their views toward tourism services asserting the lack of tourism services (Schneider, 1999). The researcher highlighted the need for enhancing and developing the tourism services. Alshourah (2001) has examined the effect of tourism services in building the destination image. The research results indicated that the safety and security attribute is among the most important attributes in the formation of Jordan image.

Harahsheh (2009) has analysed the image of Jordan as a tourist destination as perceived by British and Swedish tourists. The study also has explored the influence of religious beliefs upon the shaping of Jordan image. The results showed that perceptions of Jordan were more positive in Britain than in Swede. A large majority of respondents in both countries rated Jordan highly in all the attributes in the survey. In comparing the pre -and -post visitation surveys, the results indicated that the image of Jordan held by the British and Swedish tourist is modified positively for 14 attributes and negatively for nine others.

\section{Research Methodology}

To carry out this research non-Arab tourists visiting Jordan were surveyed by using a structured English questionnaire that consisted of statements about tourism attributes adapted from Beerli and Martín (2004). The survey took place between 20 November 2009 and 25 April 2010. The respondents were asked about their demographic variables, the nature of their trip to Jordan, and then they were asked to rate an 18 developed statements on Jordan attributes based on their level of agreement. The assessment was on a 5 -point Likert scale from 1(strongly disagree) to 5 (strongly agree). A total of 179 questionnaires were useful for statistical analysis. 
Data collection was accomplished with the assistance of five tour guides who joined the tourists during their stay in Jordan. The purpose of selecting the tour guides in the collection process is based upon the researchers' belief in the importance of tour guides as valuable indirect tools of data gathering. Their exceptional position as close and day-to-day contactors with tourists eased the procedure of filling the questionnaires. On the other hand, the tour guides may be seen as direct tools to collect tourism information such as destination performance and tourist behaviour (Aloudat, 2010).

In this study, the tour guides were asked to choose randomly one tourist out of five tourists to fill a questionnaire. The aim of this process is to diversify and spread the sample through different groups visiting Jordan (this diversity includes countries of origin, ages, gender, purpose and the nature of the trip) therefore, obtain different viewpoints and avoid repetition and imitation(Geoffrey,2004:289). The survey was carried out in two stages. The former survey was undertaken in the first day of the trip in the way from the airport to the hotel. The tourists in this stage were asked to answer questions on their demographic characteristics, their motivation to visit Jordan, and on their expectations about Jordan tourism attributes. The questionnaires then were handed to the tour guides except the part that consisted of the same statements answered about tourism attributes in the pre-visitation survey. The post -survey was conducted in the last day of the trip during the way back to the airport. Additional questions were answered in the post visitation survey about the overall perception on Jordan after finishing the trip. This included issues such as recommending Jordan to friends and relatives, the possibility to repeat the visit to Jordan, and the overall tourism experience. To find out the results, the study based in the following statistical tests: the Paired sample T-Test was used to compare between the pre- and post images of Jordan; the one-sample T-Test to find the results about the overall satisfaction on Jordan; and finally for reliability testing Cronbach's alpha was calculated to test for the internal consistency. The value of Cronbach's alpha was 0.903 .

\section{Results and Discussion}

This study compared between the pre- visit image and the post-visit image perceptions of the same sample of tourists visiting Jordan. Most of the respondents were male (53.6 percent), aged 60 and over (35.8 percent), and first time visitors (93.9percent). The high percentage of the sample from first time visitors enhances the reliability of the results as the level of familiarity of Jordan is relatively low. The length of stay was 6.92 nights with the lion share to Amman the capital followed by Petra. The most important information sources prior to actual visitation were exhibitions, the internet, travel agencies and the WOM of friends. The level of information provided was rated as excellent (35.5 percent), while 6.8percent thought that the information was weak. The motivations that made the respondents visit Jordan are demonstrated in table 1 with the weight and rate of each motivation.

Table 1. Tourist motivation for visiting Jordan

\begin{tabular}{|c|c|c|c|c|c|c|c|c|c|c|c|c|}
\hline \multirow{2}{*}{$\begin{array}{l}\text { Motivation } \\
\text { Scale }\end{array}$} & \multicolumn{2}{|c|}{$\begin{array}{l}\text { FREQUENCY } \\
\text { Less important }\end{array}$} & \multicolumn{3}{|c|}{ More important } & \multicolumn{5}{|c|}{$\begin{array}{l}\text { WEIGHT } \\
\text { Less important }\end{array}$} & \multirow[t]{2}{*}{$\begin{array}{l}\text { Total of } \\
\text { Weights }\end{array}$} & \multirow[t]{2}{*}{ RANK* } \\
\hline & 1 & 2 & 3 & 4 & 5 & 1 & 2 & 3 & 4 & 5 & & \\
\hline Climate & 40 & 14 & 67 & 56 & 2 & 40 & 28 & 201 & 224 & 10 & 503 & 7 \\
\hline Natural beauty & 34 & 14 & 44 & 34 & 53 & 34 & 28 & 132 & 136 & 265 & 595 & 3 \\
\hline Historical sites & 4 & 2 & 16 & 48 & 109 & 4 & 4 & 48 & 192 & 545 & 793 & 2 \\
\hline Sport events & 145 & 10 & 14 & 6 & 4 & 145 & 20 & 42 & 24 & 20 & 251 & 12 \\
\hline Spa sites & 139 & 22 & 12 & 4 & 2 & 139 & 44 & 36 & 16 & 10 & 245 & 13 \\
\hline Dead sea & 20 & 22 & 59 & 42 & 36 & 20 & 44 & 177 & 168 & 180 & 589 & 4 \\
\hline Petra & 4 & - & 10 & 33 & 132 & 4 & - & 30 & 132 & 660 & 826 & 1 \\
\hline City visit & 70 & 33 & 52 & 18 & 6 & 70 & 66 & 156 & 72 & 30 & 394 & 9 \\
\hline Heritage sites & 38 & 26 & 42 & 38 & 35 & 38 & 52 & 126 & 152 & 175 & 543 & 5 \\
\hline Religious sites & 46 & 30 & 50 & 22 & 31 & 46 & 60 & 150 & 88 & 155 & 499 & 8 \\
\hline Prices & 68 & 36 & 61 & 12 & 2 & 68 & 72 & 183 & 48 & 10 & 381 & 11 \\
\hline Museums & 68 & 46 & 39 & 20 & 6 & 68 & 92 & 117 & 80 & 30 & 387 & 10 \\
\hline Safety and & 38 & 26 & 66 & 27 & 22 & 38 & 52 & 198 & 108 & 110 & 506 & 6 \\
\hline
\end{tabular}

security

* The rank was calculated as follows: the frequency $\times$ scale $=$ weight, and then the total of weight were given ranking. 
Table (1) shows that Petra was considered as the first motivation for the respondents to visit Jordan. Petra is Jordan's most visited attraction and the first to be designated, by UNESCO, as a world heritage site in Jordan. In the 7th of July 2007 it was voted as one of the New Wonders of the World. At the end of 2007, it was visited by around 600000 visitors with a relative change of 61.7 percent than in 2006 (MOTA, 2006-2007). Historical sites, natural beauty, Dead Sea, and heritage sites were also from the strongest motivations for the respondents to visit the country. Spa tourism, and sport events were the lowest in terms of travel motivation.

\subsection{A Comparison between the Pre- and Post-Visitation Image}

A tabulation of the results on the pre -and post-images is presented in table 2 . It reveals the differences between the two images in the 18 attributes. The results were calculated using the paired Sample T test.

Table 2. Comparison between the pre-visit and the post-visit image

\begin{tabular}{|c|c|c|c|c|c|c|}
\hline List of 18 attributes & Image & Mean & $\begin{array}{c}\text { The difference } \\
\text { between the } \\
\text { two means }\end{array}$ & T-Value & $\begin{array}{l}\text { Ranking of } \\
\text { attribute }\end{array}$ & $\begin{array}{c}\text { Statistical } \\
\text { significance }\end{array}$ \\
\hline Safety and security & $\begin{array}{l}\text { Pre } \\
\text { Post }\end{array}$ & $\begin{array}{l}3,58 \\
4,42\end{array}$ & 0,84 & $-12,338$ & 2 & 0,00 \\
\hline Accessibility & $\begin{array}{l}\text { Pre } \\
\text { Post }\end{array}$ & $\begin{array}{l}3,42 \\
3,91\end{array}$ & 0,49 & $-7,734$ & 5 & 0,00 \\
\hline Cleanliness & $\begin{array}{l}\text { Pre } \\
\text { Post }\end{array}$ & $\begin{array}{l}3,06 \\
3,39\end{array}$ & 0,33 & $-3,770$ & 9 & 0,00 \\
\hline Natural beauty & $\begin{array}{l}\text { Pre } \\
\text { Post }\end{array}$ & $\begin{array}{l}3,48 \\
4,11\end{array}$ & 0,63 & $-12,338$ & 4 & 0,00 \\
\hline Climate & $\begin{array}{l}\text { Pre } \\
\text { Post }\end{array}$ & $\begin{array}{l}3,45 \\
3,76\end{array}$ & 0,31 & $-7,734$ & 6 & 0,00 \\
\hline $\begin{array}{l}\text { Diversity in tourism } \\
\text { resources }\end{array}$ & $\begin{array}{l}\text { Pre } \\
\text { Post }\end{array}$ & $\begin{array}{l}3,97 \\
4,30\end{array}$ & 0,33 & $-3,770$ & 3 & 0,00 \\
\hline $\begin{array}{l}\text { Accommodation } \\
\text { services }\end{array}$ & $\begin{array}{l}\text { Pre } \\
\text { Post }\end{array}$ & $\begin{array}{l}3,03 \\
3,55\end{array}$ & 0,52 & $-9,246$ & 8 & 0,00 \\
\hline Friendliness & $\begin{array}{l}\text { Pre } \\
\text { Post }\end{array}$ & $\begin{array}{l}3,49 \\
4,30\end{array}$ & 0,81 & $-3,849$ & 3 & 0,00 \\
\hline Transport services & $\begin{array}{l}\text { Pre } \\
\text { Post }\end{array}$ & $\begin{array}{l}3,03 \\
3,55\end{array}$ & 0,52 & $-4,273$ & 8 & 0,00 \\
\hline Shopping activities & $\begin{array}{l}\text { Pre } \\
\text { Post }\end{array}$ & $\begin{array}{l}2,63 \\
2,91\end{array}$ & 0,28 & $-11,851$ & 12 & 0,00 \\
\hline Night activities & $\begin{array}{l}\text { Pre } \\
\text { Post }\end{array}$ & $\begin{array}{l}1,99 \\
2,24\end{array}$ & 0,25 & $-6,618$ & 15 & 0,00 \\
\hline Sports facilities & $\begin{array}{l}\text { Pre } \\
\text { Post }\end{array}$ & $\begin{array}{l}2,15 \\
2,46\end{array}$ & 0,31 & $-4,614$ & 14 & 0,00 \\
\hline Spa services & $\begin{array}{l}\text { Pre } \\
\text { Post }\end{array}$ & $\begin{array}{l}2,41 \\
2.81\end{array}$ & 0,40 & $-4,683$ & 13 & 0,00 \\
\hline $\begin{array}{l}\text { Tour guides' } \\
\text { performance }\end{array}$ & $\begin{array}{l}\text { Pre } \\
\text { Post }\end{array}$ & $\begin{array}{l}3,51 \\
4,46\end{array}$ & 0,95 & $-10,346$ & 1 & 0,00 \\
\hline Price level & $\begin{array}{l}\text { Pre } \\
\text { Post }\end{array}$ & $\begin{array}{l}2,94 \\
3,06\end{array}$ & 0,12 & $-1,323$ & 12 & 0,18 \\
\hline Tourism restaurants & $\begin{array}{l}\text { Pre } \\
\text { Post }\end{array}$ & $\begin{array}{l}3,06 \\
3,24\end{array}$ & 0,18 & $-2,266$ & 11 & 0,00 \\
\hline $\begin{array}{l}\text { Airport entry } \\
\text { procedures }\end{array}$ & $\begin{array}{l}\text { Pre } \\
\text { Post }\end{array}$ & $\begin{array}{l}3,94 \\
3,58\end{array}$ & 0,64 & $-8,651$ & 7 & 0,02 \\
\hline Museums & $\begin{array}{l}\text { Pre } \\
\text { Post }\end{array}$ & $\begin{array}{l}3,15 \\
3,26\end{array}$ & 0,11 & $-1,471$ & 10 & 0,134 \\
\hline
\end{tabular}

The results represented in table 2 were analysed using the paired sample test. The general observation that can be noticed is that the respondents experienced the performance of Jordan as higher than what they expected. In other words, the actual experience was higher than the expectations.

The results demonstrated that the post-image was evaluated as higher than the pre- image with respects to all of the attributes except of that one related to price levels. The respondents expected that the prices are lower than what they actually experienced. Similar findings on the price level were demonstrated by Jordanian tour guides who 
perceived that the price in Jordan is high, especially when compared to the prices of competing destinations in the region. They asserted the need to review and monitor the prices of tourism services, including accommodation and food and beverage prices. In the latest report of the Travel and Tourism Competitiveness Index, Jordan ranked 37 compared with 2 for Egypt, 4 for Bahrain, and 13 for Tunisia in price competitiveness.

When found out the differences between the means of the pre- and post- images of each attribute, the highest difference was for the attributes of: tour guiding service, safety and security, friendliness, diversity in tourism resources, and natural beauty respectively. The accessibility, climate, accommodation services, airport entry procedures, transport service, cleanliness, tourism restaurants, and museums were assessed as fair. The lowest mean went to the price levels, shopping activities, spa services, sport activities, and night life.

The relationships between the pre-image and the post -image of Jordan and the tourists' gender, the tourists' age, the number of visits to Jordan, and the source of information about Jordan were also assessed. The results showed that there is no statistical significance in the pre-visitation survey and in the post - visitation survey in relation to tourists' gender. However, the age of tourists showed significance in both images with the highest mean for the tourist aged 60 and over and those aged from 50-59. These findings may be explained in that the main stream in Jordan is the cultural tourism, the sort of tourism that appeals older tourists (Rawashdeh, 2006). According to the number of visits, statistical significance was not found in the pre- image while found in the post -image with high means in the category that visited Jordan for three times and more. Therefore, the image of Jordan differed depending on the number of visits. This may be explained as, the more the numbers of visits are, the more the real image is comprehensively formulated. Additionally, tourists' satisfaction resulted in repeating visits to Jordan. Finally, there was a statistical significance only in the post-image in relation to the level of information prior to the actual visitation. The highest mean was for the category that gained excellent information about Jordan. This reflects the importance of the promotional activities that the destination should carry out because of its influence in the image formulation.

At last, the destination post-visitation performance was rated through final six questions about the overall satisfaction on Jordan performance as a tourism destination. The results were found out using the one-sample $\mathrm{T}$ test as table 3 below shows.

Table 3. After holiday experience

\begin{tabular}{llllc}
\hline Statements & Mean & $\begin{array}{l}\text { Standard } \\
\text { deviation }\end{array}$ & T -value & Sig \\
\hline 1-Did you get a good experience in Jordan? & 4.45 & 0.751 & 25.882 & 0.00 \\
2-Will you recommend Jordan for your friends and relatives? & 4.37 & 0.757 & 24.299 & 0.00 \\
3-Your overall satisfaction about Jordan? & 4.15 & 0.730 & 21.084 & 0.00 \\
4-Did Jordan performance went beyond your expectation? & 4.05 & 0.914 & 15.382 & 0.00 \\
5- If you have the opportunity in the future to travel, will you & 3.99 & 1.068 & 12.458 & 0.00 \\
choose Jordan again? & & & & \\
6-Did you experience a good hospitality in Jordan? & 3.10 & 1.195 & 1.126 & 0.26 \\
\hline
\end{tabular}

According to the means in table 3 a general observation can be noted that the tourists get a good experience in Jordan, they will recommend Jordan for their friends and relatives, and that there was an overall satisfaction about Jordan as a tourism destination. Further, the respondents perceive that the performance of Jordan as a tourism destination went beyond their expectations. The findings revealed that the tourists may repeat their visit to Jordan in the future. Additionally, the respondents experienced the hospitality of Jordanian people although this question was statistically significant, thus, hospitality was not notably felt and this may be due to the limited encounter that occurs between the tourists and the local people during their stay in Jordan.

\section{Conclusion}

This study primary aim was to track the image of Jordan using the same sample. Based on the tourists' perceptions in the pre- and post -visit surveys, the results indicated that Jordan image was moved positively in the postvisitation survey in all of the attributes except for the price levels. The respondents rated highly the attributes of tour guiding, safety and security, and the friendliness of the Jordanian people. The study results emphasized that Petra was considered as the first motivation for the tourists to visit Jordan. Furthermore, the study revealed that there was an overall satisfaction from the respondents about Jordan as a tourism destination. According to the results, it is pointed out that Jordan is not promoted properly as its actual performance. 


\section{References}

Aloudat, A. Sh. (2010). The Worldview of Tour Guides: A Grounded Theory Study (Doctoral Dissertation). Submitted to the University of Bedfordshire, UK.

Alshourah, M. (2001). Market segmentation and the formulation of image: a study of inbound tourism to Jordan. Mu'tah Journal for Research and Studies (MJRS), 16(6), 125-160.

Baloglu, S., \& McCleary, K. W. (1999). A model of destination image. Annals of Tourism Research, 26(4), 868-897. http://dx.doi.org/10.1016/S0160-7383(99)00030-4

Beerli, A., \& Martin, J. D. (2004). Tourists' characteristics and the perceived image of tourist destinations: a quantitative analysis - a case study of Lanzarote. Spain. Tourism Management, 25, 623-636. http://dx.doi.org/10.1016/j.tourman.2003.06.004

Choi, S., Lehto, X. Y., \& Morrison, A. M. (2007). Destination image representation on the web: content analysis of Macou travel related websites. Tourism Management, 28, 118-129. http://dx.doi.org/10.1016/j.tourman.2006.03.002

Chon, K. S. (1990). The role of destination image in tourism: a review and discussion. Tourist Review, 45(2), 2-9. http://dx.doi.org/ 10.1108/eb058040

Chon, K. S. (1991). Tourism destination image modification process: marketing implication. Tourism Management, 12(1), 68-72. http://dx.doi.org/10.1016/0261-5177(91)90030-W

Crompton, J. L. (1979). An assessment of the image of Mexico as a vacation destination and the influence of geographical location upon that image. Journal of Travel Research, 18-23. http://dx.doi.org/10.1177/004728757901700404

Echtner, C., \& Ritchie, J. R. (1991). The meaning and measurement of destination image: An Empirical Assessment. Journal of Travel Research, 31(4), 13-43. http://dx.doi.org/ 10.1177/004728759303100402

El-Roudan, F., Al-Ardah, F., \& Tal'at, B. (2000). Tourism Economics in Jordan, Essential Facilities and Marketing. Royal Scientific Society, Computer Technology Training and Industrial Studies Center. Amman.

Fakeye, P. C., \& Crompton, J. L. (1991). Image differences between prospective, first time, and repeat visitors to the Lower Rio Grande Valley. Journal of Travel Research, 30, 10-16. http://dx.doi.org/10.1177/004728759103000202

Gallarza, M. G., Saura, I. G., \& Garcia, H. C. (2002). Destination image: towards a conceptual Framework. Annals of Tourism Research, 29(1), 56-78. http://dx.doi.org/10.1016/S0160-7383(01)00031-7

Gartner, W. C. (1994). Image formation process. Journal of Travel and Tourism Marketing, 2(2/3), 191-215. http://dx.doi.org/10.1300/J073v02n02_12

Gertner, D., \& Kotler, P. (2004). How can a place correct a negative image? Place Branding, 1(1), 50-57.

Goodrich, J. N. (1978). A new approach to image analysis through multidimensional scaling. Journal of Travel Research, 16(3), 3-7. http://dx.doi.org/10.1177/004728757801600302

Gray, M. (2002). Development Strategies and the Political Economy of Tourism in Contemporary Jordan. In E. Joffe (Ed.), Jordan in Transition (pp. 308-329). London: Hursand and Co. Publishers.

Grosspietsh, M. (2004). Perceived and projected images of Rawanda: visitor and international tour operator perspectives. Tourism Management, 27(2), 225-234. http://dx.doi.org/10.1016/j.tourman.2004.08.005

Gunn, C. (1972). Vacationscape. Designing Tourist Regions. Washington DC: Taylor and Francis/University of Texas.

Harahsheh, S. (2009). An Evaluation of the Image of Hashemite Kingdome of Jordan in the British and Swedish Markets and the Implications for Marketing the Country as a Tourism Destination. (Doctoral Dissertation). Bournemouth University.

Hunt, J. D. (1975). Image as a factor in tourism development. Journal of Travel Research, 13, 1-7. http://dx.doi.org/10.1177/004728757501300301

Jenkins, O. H. (1999).Understanding and measuring tourist destination images. International Journal of Tourism Research, 1, 1-15.

Kim, S. S., Mckercher, B., \& Lee, H. (2009). Tracking tourism destination image perception. Annals of Tourism Research, 36(4), 715-718. http://dx.doi.org/10.1016/j.annals.2009.04.007 
Lin, C. T., \& Huang, Y. L. (2009).Mining tourist imagery to construct destination image position model. Expert System with Application, 36, 2513-2524. http://dx.doi.org/10.1016/j.eswa.2008.01.074

Mayo, E., \& Jarvis, L. (1981). The Psychology of Leisure Travel. Boston: CBI.

Mazanec, J., \& Wöber, K. (2010). Analysing International City Tourism (2nd ed.). New York: Springer Wien.

Ministry of Tourism and Antiquities (MOTA). National Tourism Strategy 2011-2015. Retrieved from http://www.mota.gov.jo/en/portals/0/NTS_2011-2015_English.pdf

Ministry of Tourism and Antiquities (MOTA). Retrieved from http://www.mota.gov.jo/en/Default.aspx?tabid=121

Pearce, P. L. (1982). Perceived changes in holiday destinations. Annals of Tourism Research, 9, 145-164. http://dx.doi.org/10.1016/0160-7383(82)90044-5

Pearce, P. L. (1988). The Ulysses Factor: Evaluating Visitors in Tourist Settings. New York: Springer-Verlag.

Pike, S. (2002). Destination image analysis-a review of 142 papers from 1973-2002, programme, Waiariki Institute of Technology, Private Bag, Rotorua, New Zealand. Tourism Management, 23, 541-549.

Rawashdeh, A. (2006). The Governance Forms of the Value Chain of International Tourism to Jordan. Unpublished PHD thesis, University of Jordan, Amman.

Reid, M., \& Schwab, W. (2006).Barriers to Sustainable Development: Jordan's Sustainable Tourism Strategy. Journal of Asian and African Studies, 41(5/4), 439-457.

Reid, R. D., \& Bojanic, D. C. (2009). Hospitality Marketing Management. Hoboken, New Jersy: John Wiley and Sons.

Schneider, I., \& Sönmez, S. (1999). Exploring the touristic image of Jordan. Tourism Management, 20, 539-542.

Travel and Tourism Competitiveness Report. (2008). World Economic Forum, Geneva.

Wang, Y., \& Davidson, M. (2010). Pre-and post-trip perceptions: an insight into Chinese package holiday Market to Australia. Journal of Vacation Marketing, 16(2), 111-123. 